\title{
EFFECT OF SOIL MOISTURE AND TEMPERATURE ON SURVIVAL OF MICROBIAL CONTROL AGENTS
}

\author{
M. O'CALLAGHAN, E.M. GERARD and V.W. JOHNSON
}

Biocontrol and Biosecurity, AgResearch, PO Box 60, Lincoln

Corresponding author: maureen.ocallaghan@agresearch.co.nz.

\begin{abstract}
Microbial control of soil dwelling pests and pathogens depends on the survival of microbial inocula in soil. Three microbes, Beauveria bassiana A6, Serratia entomophila 626, and Pseudomonas fluorescens CHA0-Rif, were inoculated into soil microcosms at three soil moistures and temperatures. Survival was determined at regular intervals. Beauveria bassiana survived well in soil; after 3 months the populations were maintained at levels close to those immediately following inoculation under most soil conditions Serratia entomophila and P. fluorescens populations declined gradually. Soil moisture impacted on survival of $P$. fluorescens, with populations declining most rapidly in the dry soil at all temperatures. Pseudomonas fluorescens was not recovered after 54 days at $20^{\circ} \mathrm{C}$. The rate of population decline of S. entomophila increased with soil temperature but populations remained above the minimum level of detection after three months, with soil moisture having little effect on survival. Formulation of $S$. entomophila into granules greatly improved the survival of this bacterium in soil.

Keywords: microbial control, soil inoculation, establishment, formulation.
\end{abstract}

\section{INTRODUCTION}

Microbial control of soil-dwelling pests and pathogens depends on the successful establishment and survival of microbial inocula in soil. While microbial control agents are often effective in the laboratory, the level of pest control achieved in the field is sometimes disappointing and unpredictable. Some of these failures can be attributed to inadequate establishment and survival of microbial inocula in soil (Elliot \& Lynch 1995).

Microbial insect pathogens typically vary in their ability to persist in the soil after field application. For example, conidia of the entomopathogenic fungus Beauveria bassiana declined to undetectable levels within two months after application (Groden \& Dunn 1996), while populations of another fungal insect pathogen Metarhizium anisopliae were maintained for over one year after application (Glare et al. 1994). While spores of the bacterial insect pathogen Bacillus popillae can survive in soil for many years, a greater challenge is the establishment of populations of non-sporeforming bacteria. Populations of the non-sporeforming bacterium Serratia entomophila (Enterobacteriaceae) are applied to pasture for control of the New Zealand grass grub Costelytra zealandica (Jackson et al. 1992). Populations of other beneficial bacteria, for example Rhizobium spp. and plant growth-promoting rhizobacteria such as Pseudomonas spp., also decline following application to soil. Minimising postapplication decline of microbial inocula applied to soil would improve the efficacy of microbial control agents, but this will not be achieved without understanding the reasons for the observed declines. Environmental factors will be critical.

Formulations of micro-organisms have been developed to overcome some of the adverse conditions encountered by microbial inocula entering the soil. The formulations may include large amounts of carriers, selective food sources or buffers that can transiently alter the microphysical environment of the soil to provide a temporary safe haven (Paau 
1998). Thus, the formulation provides the inocula with time and space to reactivate, adjust physiologically to the new environment and propagate.

Short-term soil microcosm experiments were undertaken to determine the impact of soil moisture and temperature on establishment and survival of microbial inocula. Three microbial control agents (the fungus B. bassiana and bacteria S. entomophila and Pseudomonas fluorescens) were monitored for their ability to establish and survive in soil. In addition, one of the bacteria was formulated into a granule and its survival in soil monitored at two soil moisture levels.

\section{MATERIALS AND METHODS}

Microbial control agents

The three microbial control agents used in experiments are held in the Microbial Control/Insect Pathogen Culture Collection, AgResearch, Lincoln. Deuteromycete fungus B. bassiana strain A6 was isolated from a weevil (Sitona sp.) at Montpellier, France, during surveys to isolate potential control agents for the clover root weevil, Sitona lepidus. Laboratory bioassays at AgResearch, Lincoln, indicated that this strain is pathogenic to clover root weevil (T. Nelson, pers. comm.). Two non-sporeforming bacteria were used. Pseudomonas fluorescens strain CHA0-Rif, a soil isolate, is active against a range of plant pathogenic fungi (Defago \& Haas 1990) and has been marked with a rifampicinresistance marker to facilitate its selective recovery. Serratia entomophila strain 626 was originally isolated from pasture soil in Canterbury and is pathogenic to the New Zealand grass grub.

\section{Production of microbial inocula}

Serratia entomophila and $P$. fluorescens were cultured by inoculating a $100 \mathrm{ml}$ broth ( $4 \mathrm{~g}$ raw sugar, $1 \mathrm{~g}$ yeast extract, $0.2 \mathrm{~g}$ urea and $0.2 \mathrm{~g} \mathrm{NPK}$ ) with $1 \mathrm{ml}$ of an overnight culture and incubated with shaking $(180 \mathrm{rpm})$ at $30^{\circ} \mathrm{C}$ for $48 \mathrm{~h}$. Cell counts were determined by serial dilution plating on Luria Bertani agar (Sambrook et al. 1989). Beauveria bassiana was grown on PDA plates (Merck) for $14-20$ days at $25^{\circ} \mathrm{C}$ to allow for sporulation. Spores were harvested from the plates into $0.01 \%$ Triton-X (BDH) and enumerated using a haemocytometer (Neaubauer Improved) to give a suspension of $10^{8} \mathrm{spores} / \mathrm{ml}$. Soil microcosms (containing $20 \mathrm{~g}$ soil dry weight) were inoculated with one of the microbial control agents to give approximately $10^{6}$ colony forming units $(\mathrm{cfu}) / \mathrm{g}$ air dried soil.

Soil microcosms

Field soil (Wakanui silt loam) was collected from near the AgResearch farm compound at Lincoln. Soil was sieved and stored at $4^{\circ} \mathrm{C}$ until used. The soil had $\mathrm{pH}$ of 6.3 and organic matter content of $5.4 \%$. Soil moisture content was determined by drying $20 \mathrm{~g}$ soil at $60^{\circ} \mathrm{C}$ for $24 \mathrm{~h}$. Samples of the soil were either air-dried or moistened with tap water to give the required soil moisture contents of $13 \%, 23 \%$ and $30 \%(w / w)$. The equivalent of $20 \mathrm{~g}$ dry weight of soil was added to $30 \mathrm{ml}$ sterile plastic tubes. After application of microbial inocula, the microcosms were incubated in constant temperature cabinets $\left(10^{\circ} \mathrm{C}, 15^{\circ} \mathrm{C}\right.$ or $\left.20^{\circ} \mathrm{C}\right)$. The experiment was terminated when microbial populations declined to below the limit of detection (approximately $10^{2} \mathrm{cfu} / \mathrm{g}$ soil).

\section{Recovery of inoculum from soil}

Forty-five tubes were sampled for each microbial control agent at each sampling interval ( 3 moisture levels x 3 temperatures x 5 replicate tubes). Microbial inocula were recovered by serial dilution plating of each $20 \mathrm{~g}$ soil sample in $180 \mathrm{ml}$ of sterile peptone water $(0.1 \% \mathrm{w} / \mathrm{v}$; Oxoid $)$ and spread plating onto appropriate selective agars. Beauveria bassiana populations were enumerated on PDA containing cycloheximide (BDH, UK; $125 \mathrm{mg} /$ litre), streptomycin sulphate (Sigma; $350 \mathrm{mg} /$ litre) and tetracycline (Sigma; $50 \mathrm{mg} /$ litre) after incubation for 5 days at $23^{\circ} \mathrm{C}-25^{\circ} \mathrm{C}$. Pseudomonas fluorescens was enumerated on P1 agar (Katoh \& Itoh 1983) containing $100 \mathrm{mg} /$ litre rifampicin (Sigma) following incubation at $30^{\circ} \mathrm{C}$ for 4 days. Serratia entomophila were enumerated on caprylate thallous agar (Starr et al. 1976) after incubation for 6 days at $30^{\circ} \mathrm{C}$. Identity of colonies was verified as described 
previously (O'Callaghan \& Jackson 1993). Uninoculated control soils were sampled at each date to determine the background populations of the three inoculant species. No background bacterial populations were detected.

\section{Formulation of bacteria}

Serratia entomophila was formulated into granules using methods developed at AgResearch, Lincoln, for the stabilisation of non-sporeforming bacteria (NZ Patent 50687). Briefly, broth cultures were concentrated by centrifugation and then incorporated in a biopolymer matrix. Extruded clay-based granules were 1-3 $\mathrm{mm}$ in size with a moisture content of $35-40 \%$. Bacterial loading on the granules was estimated by dilution plating on LB agar. Granules were inoculated into soil microcosms to give a rate of approximately $10^{7} \mathrm{cfu} / \mathrm{g}$ air dried soil. The soil in microcosms was adjusted to either 13 or $22 \%$ moisture content $(\mathrm{w} / \mathrm{w})$ by addition of tap water prior to inoculation.

Statistical analysis

Numbers of colony forming units (cfu)/g soil were $\log _{10}$ transformed before analysis of variance (Genstat). A constant value of 40 was added to counts of the bacteria before transformation, this value being the minimum number of colonies recovered by the plating technique used.

\section{Beauveria bassiana}

\section{RESULTS}

Spores of $B$. bassiana A6 survived well in soil at 10 and $15^{\circ} \mathrm{C}$, with the populations close to the initial levels at all soil moisture levels after 123 days (Fig. 1). At $20^{\circ} \mathrm{C}$, the

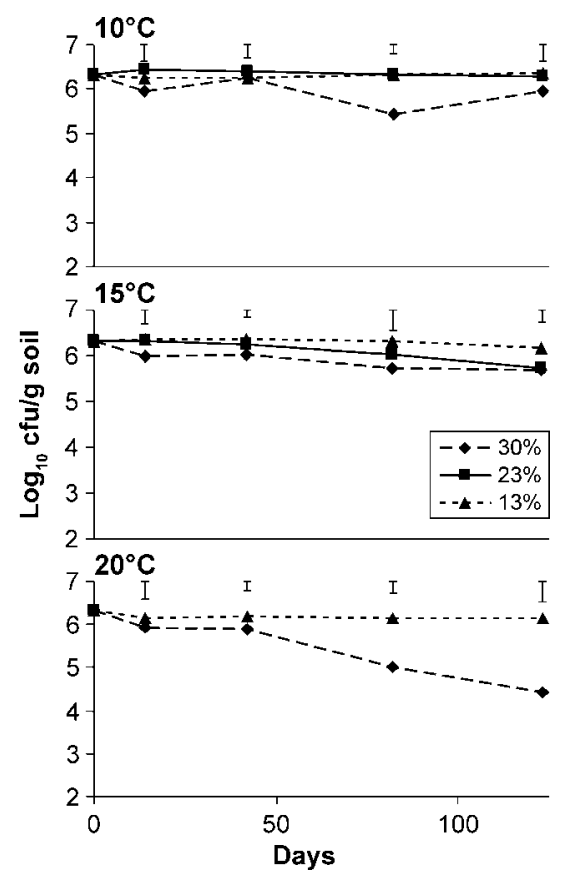

FIGURE 1: Numbers of colony forming units/g soil (dry weight) of Beauveria bassiana $\mathrm{A} 6$ remaining at three soil moisture contents $(\mathrm{w} / \mathrm{v})$ at $10^{\circ} \mathrm{C}$, $15^{\circ} \mathrm{C}$ and $20^{\circ} \mathrm{C}$. Error bars are LSD $(\mathbf{P}<0.05)$ 
rate of decline of the populations varied significantly (Fig. 1); in soil held at 13\% moisture, there was no loss of viability, while at $30 \%$ moisture the population had declined by more than one log after 3 months. In contrast, after only 14 days incubation in soil at $20^{\circ} \mathrm{C}$ with moisture content of $23 \%$, no fungal inoculum was recovered. This finding was confirmed on subsequent sampling dates.

Pseudomonas fluorescens

Establishment of $P$. fluorescens was significantly affected by both soil moisture content and temperature (Fig. 2). At $10^{\circ} \mathrm{C}$, the population had declined after 110 days from $8 \times 10^{5}$ cfu/g soil to approximately $7 \times 10^{3}$ and $1 \times 10^{4} \mathrm{cfu} / \mathrm{g}$ soil in soil at 30 and $23 \%$ moisture content respectively, while $1 \times 10^{3} \mathrm{cfu} / \mathrm{g}$ remained in the driest soil. In soil incubated at $15^{\circ} \mathrm{C}$, populations in all soil moisture levels had declined to between $3-5 \times 10^{2} \mathrm{cfu} / \mathrm{g}$ soil after 110 days $\left(<0.05 \%\right.$ of inoculum remaining). At $20^{\circ} \mathrm{C}$, population decline was much greater, with populations falling to below the level of detection at all soil moisture levels after 54 days. When sampled at 82 days, $P$. fluorescens could not be recovered from most replicate samples held at $20^{\circ} \mathrm{C}$, so statistical analysis of the data was not possible.

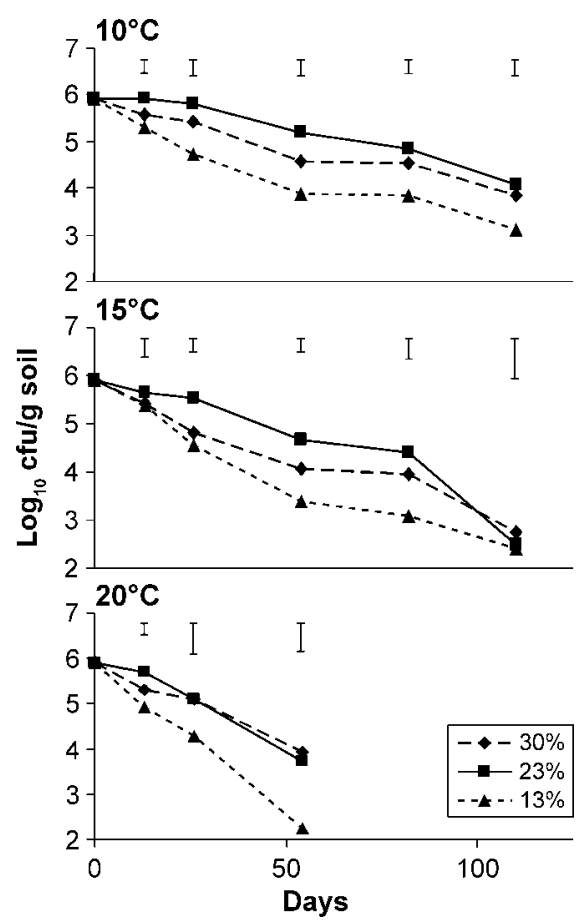

FIGURE 2: Numbers of colony forming units/g soil (dry weight) of Pseudomonas fluorescens CHAO-Rif remaining at three soil moisture contents $(\mathrm{w} / \mathrm{v})$ at $10^{\circ} \mathrm{C}, 15^{\circ} \mathrm{C}$ and $20^{\circ} \mathrm{C}$. Error bars are $\operatorname{LSD}(\mathbf{P}<0.05)$.

\section{Serratia entomophila}

Survival of S. entomophila also varied between soil temperatures and moistures (Fig. 3). While in general populations were not significantly affected by soil moisture content, populations decreased under all soil conditions, with the rate of decline increasing 
as temperature increased. At $10^{\circ} \mathrm{C}$, establishment was better at $23 \%$ moisture content until the last sampling date, when numbers of $S$. entomophila declined to a level similar to that at the other two soil moistures, with numbers of $5-85 \times 10^{2} \mathrm{cfu} / \mathrm{g}$ soil remaining at 109 days. At 15 and $20^{\circ} \mathrm{C}$, populations had declined more rapidly, reaching the minimum detectable level by 109 days.

Formulation of $S$. entomophila

Formulation of $S$. entomophila into granules significantly improved the survival of this bacterium in soil at both soil moistures tested. While the cells applied as liquid suspension declined to $1.6 \times 10^{3} \mathrm{cfu} / \mathrm{g}$ soil after 116 days at $22 \%$ moisture content,

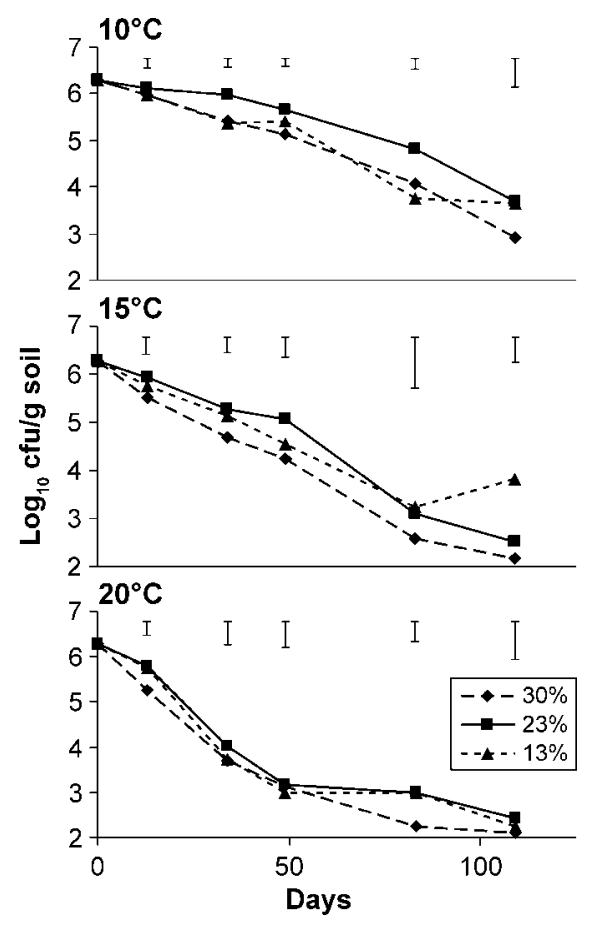

FIGURE 3: Numbers of colony forming units/g soil (dry weight) of Serratia entomophila 626 remaining at three soil moisture contents (w/v) at $10^{\circ} \mathrm{C}, 1^{\circ} \mathrm{C}$ and $20^{\circ} \mathrm{C}$. Error bars are LSD $(\mathrm{P}<0.05)$.

bacteria applied in pellet form remained viable, with numbers greater than $3 \times 10^{7} \mathrm{cfu} / \mathrm{g}$ (Fig. 4). In the drier soil (13\% moisture) at 116 days, cell numbers from soil containing granules were lower than in the more moist soil (approximately $5 \times 10^{5} \mathrm{cfu} / \mathrm{g}$ soil), but remained significantly higher than where unformulated cells were applied $\left(1 \times 10^{2} \mathrm{cfu} / \mathrm{g}\right.$ soil). Granules appeared to maintain their structure in soil for the duration of the experiment.

\section{DISCUSSION}

Beauveria bassiana is one of the most commonly used fungi for control of insect pests and forms the basis of a number of commercially available pesticides (e.g. 


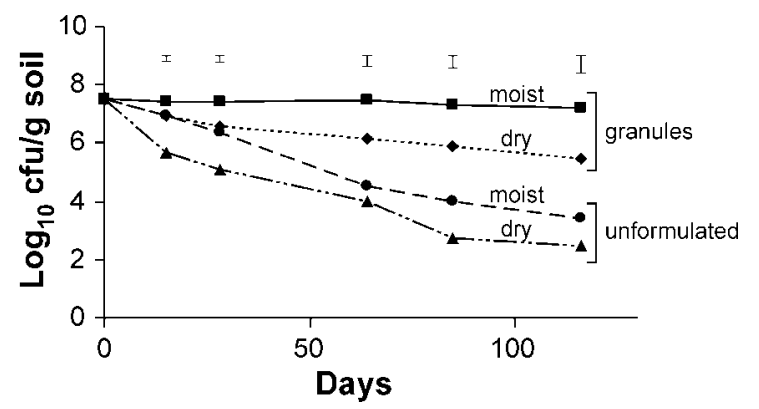

FIGURE 4: Numbers of colony forming units/g soil (dry weight) remaining in soil inoculated with $S$. entomophila, either in granules or unformulated, and held at $13 \%$ (dry) or $22 \%$ soil moisture content (moist) at $15^{\circ} \mathrm{C}$. Error bars are LSD $(\mathbf{P}<0.05)$.

BotaniGard, Mycotech). Beauveria bassiana A6 survived very well under most soil conditions tested, with little loss of inoculum, suggesting the strain could be suitable for application in the field. The only treatment not favourable for survival of spores was soil held at $20^{\circ} \mathrm{C}$ and $23 \%$ soil moisture content. Presumably these conditions allowed germination of conidia in soil. Groden \& Dunn (1996) found that soil conditions that resulted in the lowest spore germination (high $\mathrm{pH}$ and low nutrients) resulted in greatest survival and recovery of $B$. bassiana inoculum in natural soil. When $B$. bassiana is used in pest management programmes, maximum longevity of inoculum will likely be achieved under conditions that do not stimulate germination of the conidia in the absence of the host insect. Strains of this fungus vary in their ability to tolerate various environmental conditions and it may be possible to select strains suited to soil conditions encountered in areas affected by clover root weevil. Alternatively, it may be possible to formulate the conidia in such a way that they don't germinate until conditions are favourable for infection of the host.

Persistence of Pseudomonas populations in soil has been monitored by several workers as part of studies on strains with biological control potential. For example Wessendorf \& Lingens (1989) showed that P. fluorescens R1 failed to persist for long periods in natural soil. The decline of Pseudomonas populations measured in these experiments may be greater than expected as pseudomonads are typically rhizosphere colonisers and population decline may have been slower in the presence of plant roots. Nevertheless, the data indicate the sensitivity of the bacterium to soil environmental factors. Pseudomonas spp. are most often inoculated into soil as a seed coating, but these results suggest inoculum would still need careful preservation.

The loss of $S$. entomophila populations from soil at 10 and $15^{\circ} \mathrm{C}$ was similar to that observed in the field where the applied population typically declined at a rate of $1 \log$ per month (O'Callaghan 1998). More rapid losses from soil have been observed where field sites were very dry following application. Reduction in the rate of decline may lead to greater numbers of grass grub larvae becoming infected in the first season following application. Analysis of grass grub infection rates in field trials indicate that $S$. entomophila populations of at least $10^{4} \mathrm{cfu} / \mathrm{g}$ soil are required to establish disease in the grass grub population (O'Callaghan et al. 1999). In the current study, populations were maintained at the required level for approximately one month at $20^{\circ} \mathrm{C}$, more than 50 days at $15^{\circ} \mathrm{C}$ and approximately 80 days at $10^{\circ} \mathrm{C}$. In the field, S. entomophila populations in soil can be augmented through release of bacteria from infected grass grub larvae, so persistence is improved in the presence of the host insect. Timing of 
application to periods when soil moisture is adequate will improve persistence but a balance must also be achieved with respect to soil temperature; while bacterial survival may be improved at lower temperatures, the infection rate of grass grubs is also reduced as the grubs become less active at lower temperatures.

The greatly improved survival rate of $S$. entomophila when formulated into granules indicates that formulation is one method of overcoming environmental constraints to bacterial establishment following field application. Populations of S. entomophila remained above the required level to cause disease in the grass grub population for more than four months under conditions that caused rapid loss of unformulated inoculum. In this experiment, granules remained intact in soil, and estimates of bacterial numbers $/ \mathrm{g}$ soil included bacteria still contained within the granules in addition to those released into soil. Experiments are currently being conducted to examine rate of release of bacteria from the granules under various soil conditions. As this was a laboratory experiment, there was little/no activity from soil fauna, which may have increased the rate of breakdown. The results from this study indicate the enormous potential of this formulation technique for soil inoculants.

\section{ACKNOWLEDGEMENTS}

We are grateful to Prof. J.M. Lynch, University of Surrey, for provision of the Pseudomonas strain. Also Tracey Nelson, AgResearch, Lincoln, for production of fungal inoculum and assistance with recovery of Beauveria from soil and Dave Saville, AgResearch Lincoln, for statistical analysis.

\section{REFERENCES}

Defago, G.; Haas, D. 1990: Pseudomonads as antagonists of soilborne plant pathogens: modes of action and genetic analysis. Soil Biochem. 6: 249-291.

Elliot, L.F.; Lynch, J.M. 1995: The International Workshop on the Establishment of Microbial Inocula in soils. Cooperative research project on biological resource management of the Organisation for Economic Cooperation and Development (OECD). Am. J. Altern. Agric. 10: 50-73.

Glare, T.R.; Townsend, R.J.; Young, S. 1994: Temperature limitations on field effectiveness of Metarhizium anisopliae against Costelytra zealandica (White) (Coleoptera: Scarabaeidae) in Canterbury. Proc. $47^{\text {th }}$ N.Z. Plant Prot. Conf:: 266-270.

Groden, E.; Dunn, T. 1996: Germination, host infection and survival of Beauveria bassiana conidia in natural soils. In: Jackson, T.A.; Glare, T.R. ed. Proc $3^{\text {rd }}$ International Workshop on Microbial Control of Soil Dwelling Pests. AgResearch, New Zealand. ISBN 0-473-04308-4. Pp. 137-145.

Jackson, T.A.; Pearson, J.F.; O'Callaghan, M.; Mahanty, H.K.; Willocks, M. 1992. Pathogen to product - development of Serratia entomophila (Enterobacteriacae) as a commercial biological control agent for the New Zealand grass grub (Costelytra zealandica). In: Jackson, T.A.; Glare T.R. ed. Use of Pathogens in Scarab Pest Management. Intercept, Andover, UK. Pp. 191-198.

Katoh K.; Itoh, K. 1983: New selective media for Pseudomonas strains producing fluorescent pigment. Soil Sci. Plant Nut. 29: 525-532.

O'Callaghan, M.; Jackson, T.A. 1993: Isolation and enumeration of Serratia entomophila - a bacterial pathogen of the New Zealand grass grub, Costelytra zealandica. J. Appl. Bact. 75: 307-314.

O'Callaghan, M. 1998: Establishment of microbial control agents in soil. In: O'Callaghan, M.; Jackson, T.A. ed. Proc 4th International Workshop on Microbial Control of Soil Dwelling Pests, AgResearch, New Zealand. ISSN 1174-653X. Pp. 83-89.

O'Callaghan, M.; Young, S.A.; Barlow; N.B.; Jackson, T.A. 1999: The ecology of grass grub pathogenic Serratia spp. in New Zealand pastures. In: Matthiessen, J.N. ed. Proc. $7^{\text {th }}$ Australasian Conf. Grassland Invert. Ecol. Pp. 85-91. 
Paau, A.S. 1998: Formulation of beneficial organisms applied to soil. In: Burges, H.D. ed. Formulation of Microbial Biopesticides. Kluwer Academic Publishers, Dordrecht. Pp. 235-254.

Sambrook, J.; Fritsch, E.F.; Maniatis, T. 1989: Molecular cloning, $2^{\text {nd }}$ ed. Cold Spring Harbour Laboratory Press, Cold Spring Harbour, N.Y.

Starr, M.P.; Grimont, P.A.D.; Grimont, F.; Starr, P.B. 1976: Caprylate thallous agar medium for selectively isolating Serratia and its utility in the clinical laboratory. $J$. Clin. Micro. 4: 270-276.

Wessendorf, J.; Lingens, F. 1989: Effect of culture and soil conditions on survival of Pseudomonas fluorescens R1 in soil. Appl. Microbiol. Biotech. 31: 97-102. 